\title{
CAREER PLATEAUING, JOB SATISFACTION AND COMMITMENT OF SCHOLARS IN FRENCH UNIVERSITIES
}

Par Carole Drucker-Godard, Thierry Fouque, Mathilde Gollety et Alice Le Flanchec

According to Allen et al. (1999), "A number of researchers have documented that a substantial number of employees are currently experiencing a hierarchical career plateau (Burke 1989; Near 1985; Orpen 1983; Rosen and Jerdee 1988; Savery 1989; Tremblay and Roger 1993)." Career plateauing thus affects a growing number of organizations and significantly influences organizational behavior. Career plateauing describes the feeling of an individual that he/she has reached a level in the organization at which future career advancement is unlikely. While this phenomenon has been widely studied in the private sector, it has received less attention in the public sector (particularly in universities). Concerns about the effects of career plateauing have recently grown because of the decreased promotional opportunities that exist in downsized organizations. Many of today's managers will face plateauing younger than those a generation ago. For those who stay with their current employers, the challenge is how to maintain effective job performance and high job satisfaction when promotions are no longer likely.

Various factors motivate the focus on scholars in French universities. Scholars are the key resource of higher education institutions, and their performance strongly influences student success. Thus, the motivation and satisfaction of academic staff is crucial to the quality of higher education institutions (Machado et al. 2011). While previous studies have examined universities (Hosseini et al. 2013; Maden 2012), none dealt with career plateauing and its influence on academic staff performance. This study thus decided to focus on career plateauing among academic staff in French universities.

As of 2014, France has 73 universities. These are public institutions that are administered democratically and somewhat autonomous. Our study deals with the two main employment statuses of scholars in French universities: full and assistant professors. French universities have recently experienced many reforms: between 2003 and 2006, universities reformed their curriculum (in French, License, Master, Doctorat), which is now organized around three degrees. Subsequently, in 2007, the law on the freedoms and responsibilities of universities (called in French the "loi relative aux Libertés et Responsabilités des Universités") changed the status of universities by providing them autonomy in budgetary and human resource management matters, and allowing them to become property owners. This new legal framework changed the management of French universities with regard to their freedoms and responsibilities, and stimulated ongoing discussions about the evaluation of scholars. 
This study seeks to explore the current impact of career plateauing on the careers of scholars. We describe and explain the relationship of scholars with their universities, the ways in which they plan the management of their careers and their perceptions of their jobs. More precisely, we aim to identify the possible consequences of career plateauing for scholars' job commitment, satisfaction and intention to leave their university.

To answer these questions, this paper presents the results of a survey of 2,028 French scholars working in universities. This sample includes full professors and assistant professors in various disciplines (science, law, management, literature, etc.).

We first define the concepts of career plateauing, job commitment and satisfaction. Second, we establish the research hypotheses and the conceptual framework of the study. Third, we describe the methodology of this empirical study. Finally, we present the results of this quantitative study.

The findings of this study have important managerial implications. Particularly, decreased commitment and job satisfaction among academics due to career plateauing may erode the attractiveness of the profession and contribute to a decrease in the quality of education its members provide.

\section{Theoretical Background}

The following defines the notions of career plateauing, organizational and occupational commitment, and job satisfaction.

\section{Career Plateauing}

Career plateauing has been defined as "the point in a career where the likelihood of additional hierarchical promotion is very low" (Ference et al. 1977). According to Hall (1985: 272) "the career plateau is that point in an individual's organizational career at which additional upward mobility (i.e. promotion) is unlikely (Stoner et al. 1980)." This concept is relatively old, and has been studied by Ference et al. (1977), Veiga (1981), Orpen (1983), Near (1985), Slocum et al.(1985), Barwick (1986), Lemire et al. (1999) and Roger and Lapalme (2006). Several types of plateauing exist. First, we can distinguish two levels of career plateauing: structural plateauing (also called hierarchical plateauing) and job content plateauing. According to Allen et al. (1999: 1113), "Barwick (1986) initially suggested that individuals may experience two different forms of career-related plateauing: structural (i.e., hierarchical) and job content. Hierarchical plateauing results when an individual has little chance of further vertical movement within an organization. On the other hand, job content plateauing occurs when the individual is no longer challenged by his or her work or job responsibilities."

Ference et al. (1977) also identified two types of plateauing but defined them differently. First, organizational plateauing occurs when the organization does not have jobs available at higher levels of management. Second, personal plateauing occurs when an employee's abilities do not match the needs of the job which would normally lie on their career path and hence the employee decides not to seek further advancement. In either case, the realization that future promotion is unlikely may cause the employee to experience increased stress and revise his/her self-image. Barwick (1986) hypothesized that plateaued people pass through two stages: resistance and resignation. During the resistance stage, people maintain an 
expectation of achieving promotion and continue to judge their progress against a time horizon. The result is that they rededicate their commitment to the company to cope with their plateaued status. However, once they realize that they will not be promoted, they enter the resignation stage, during which they gradually withdraw from work and become passive.

Another distinction can be made between objective and subjecting plateauing. Objective plateauing is often measured based on seniority or salary. Subjective plateauing describes the feeling of the employee regarding the low probability that his/her career will continue to develop. According to Tremblay et al. (1995: 222): "two kinds of career plateauing may be defined: objective and subjective career plateauing... Objective plateauing is made up of structural and observable elements such as hierarchical and salary levels. Gattiker and Larwood (1990) as well as Barley (1989) point out the importance of the subjective side of career plateauing, which deals with the individual perception of progress and success in the future. These researchers suggest that individual perceptions and real measures of hierarchical success are actually two separate constructs." Our empirical study focuses on this latter type of plateauing, namely subjective plateauing, but also considers job content and structural plateauing.

\section{Organizational and Occupational Commitment}

Introduced by Foote (1951), the concept of commitment became popular in the 1970s. In concrete terms, organizational commitment (Mowday 1998) describes the degree to which an individual is committed to his or her organization. Mowday et al. (1979) defined organizational commitment as a "strong belief in the organization's goals and values and a willingness to exert considerable effort on behalf of the organization". Meyer and Allen (1984) initially proposed that affective and continuance commitment be distinguished. Affective commitment describes an affective or emotional attachment to an organization, while continuance commitment denotes a perceived cost associated with leaving an organization. Allen and Meyer (1990) later suggested a third component of commitmentnormative commitment - that reflects a perceived obligation to remain in an organization.

Mathieu and Zajac (1990) conducted meta-analyses of the antecedents, correlates, and consequences of organizational commitment. This project aims to estimate and compare the strength of true correlations between variables identified in Meyer and Allen (1991, 1997). Until recently, organizational commitment theory and researches have focused primarily on outcomes relevant to employers. Additionally, a growing body of research has examined the links between commitment and employee-relevant outcomes, including stress and workfamily conflict (Meyer et al. 2002).

The nature of the psychological state varies with the dimension of the commitment in question: employees with strong affective commitment remain in an organization because they want to, those with strong continuance commitment stay because they need to, and those with strong normative commitment stay because they feel obliged.

Commitment can apply to various things. Some authors have discussed career commitment (Blau 1989) while others have discussed professional commitment (Aranya et al. 1981), or job and work involvement (Kanungo 1982). Our study focuses on occupational commitment as defined by Allen et al. (1993), namely a positive attitude toward one's occupation or profession reflecting strong identification with and involvement in that occupation (Morrow and Wirth 1989). This form of commitment shares the same three dimensions as 
organizational commitment, i.e., an affective dimension (emotional attachment to an occupation), calculated dimension (costs of giving up an occupation) and normative dimension (feeling of obligation to stay in a profession).

\section{Job Satisfaction}

Job satisfaction is the general attitude of an individual towards their job. According to Locke $(\underline{1969}, 1976)$, job satisfaction is conceptualized as a positive or negative evaluation of one's job or job experiences, and refers to people's self-assessments of the extent to which they like or dislike their jobs (Spector 1997). Job satisfaction is not necessarily reflected in behavior, but describes a personal affective attitude. Job satisfaction refers to specific interactions related to this affective attitude, including pay, promotion, supervision, fringe benefits, contingent rewards, operating conditions, coworkers, nature of work, and communication (Spector 1997; Wegge et al. 2007). Buitendach and de Witte (2005) consider job satisfaction to relate to an individual's perceptions and evaluations of a job, where their perceptions in turn are influenced by individual circumstances, including needs, values and expectations. Satisfaction and dissatisfaction are non-observable variables, owing to being attitudinal. But they can lead to positive or negative behaviors (withdrawal behavior, tardiness, absenteeism, desire to leave the organization...).

A number of studies have examined the effects of career plateauing on job satisfaction, organizational commitment and intention to leave an institution. However, not all of these studies have shared a common direction. Indeed, Tremblay et al. (1995: 222) observed that "the literature in this area includes a multitude of contradictory conclusions about attitudes of those who have attained a career plateau and those who have not". Thus, the literature invites deeper exploration of the relationship between career plateauing and satisfaction, organizational and occupational commitment and intention to leave the organization. Moreover, if organizational commitment has already been explored, the relationship between plateauing and "occupational" commitment has not yet, to our knowledge, been studied in depth.

\section{Research Design}

First, we describe the relationships between scholars and their universities in terms of satisfaction and commitment. Second, we explore the impact of career plateauing on organizational and occupational commitment, job satisfaction and intention to leave the organization for French universities.

Based on our review of the literature, we first anticipate that subjective plateauing (either job content or structural) should negatively affect job satisfaction (Hypothesis 1). Second, we expect that career plateauing should negatively influence organizational commitment (Hypothesis 2) and occupational commitment (Hypothesis 3). Third, we anticipate a positive link between career plateauing and intention to leave the university (Hypothesis 4).

\section{Method}

Sample

We conducted a quantitative study to explore scholars' perceptions of the progression of their careers and of their jobs. A questionnaire was administered online to a representative sample 
of French scholars, with an open-ended question added at the end to allow respondents to express their thoughts about their jobs. These textual data were analyzed using qualitative analysis (Miles and Huberman 1994).

The questionnaire was distributed with the help of a well-known French trade union ${ }^{1}$ that allowed us to use its file of scholars in French universities for research purposes. We obtained responses from 2,028 scholars (all of them either full or assistant professors of French Universities). The sample structure is comparable to the population of scholars described by the French Ministry of Higher Education and Research in 2008/2009 (the most recent available data) and published in June 2009 (see Appendix). Table 1 reports that the sample comprised $66 \%$ men and $34 \%$ women. Additionally, assistant professors were overrepresented compared with full professors. These figures correspond to the general structure of the French population of scholars.

Table 1

Sample characteristics

\section{Percentage of total sample $(\%)$}

$\begin{array}{lr}\text { Men } & 65.7 \% \\ \text { Women } & 34.3 \% \\ \text { Assistant Professor } & 71,5 \% \\ \text { Full Professors } & 27,8 \% \\ \text { Other } & 0.7 \%\end{array}$

Measures

To measure subjective career plateauing, we adapted Milliman's scale (1992) to scholars. Meanwhile, we used the scale of Allen and Meyer (1990 and 1993), which includes 18 statements (six for each of the three dimensions of commitment: continuance, affective and normative commitment), to measure organizational and occupational commitment. Job satisfaction was assessed using the well known Minnesota Satisfaction Questionnaire (MSQ) from Weiss et al. (1967-1977), which includes 20 statements. A pre-test was performed on a few scholars, and statements that appeared inappropriate for the subject population were deleted. The final scale for measuring job satisfaction thus consisted of 18 statements. The intention to leave the university was measured by three items.

We applied the Churchill paradigm (1979) to validate our scales and conduct Factorial Analysis. Only axes with eigenvalues of 1 or greater were kept. The results of the analysis of the scales of subjective career plateauing, satisfaction and intention to leave the university were highly satisfactory since all items were retained, and the structures of the scales were consistent with previous results from the literature. However, although the scale for occupational commitment is well-structured and has three dimensions, some items were deleted from the final measurement scale structures because they did not contribute significantly to the axes that they were supposed to characterize. Besides the continuance

\footnotetext{
${ }^{1}$ The authors thank the Trade Union for allowing us to use their data. Their data file includes both scholars who are union members and those who are not, and hence can be considered to closely approximate the entire population of scholars at French universities.

${ }^{2}$ Demographic characteristics of teaching personnel working in French higher education (2008/2009), DGRH A1

-1 , June 2009.
} 
dimension of occupational commitment (0.659), all the Cronbach's alpha for the scales yielded values greater than 0.7 , which is satisfactory (Table $\underline{2}$ ).

Table 2

Reliability of measurement scales

\section{Cronbach's alpha}

$\begin{array}{lr}\text { Job satisfaction (MSQ) } & 0.857 \\ \text { Structural career plateau } & 0.902 \\ \text { Content career plateau } & 0.727 \\ \text { Affective organizational commitment } & 0.767 \\ \text { Continuance organizational commitment } & 0.740 \\ \text { Normative organizational commitment } & 0.785 \\ \text { Affective occupational commitment } & 0.832 \\ \text { Continuance occupational commitment } & 0.659 \\ \text { Normative occupational commitment } & 0.745 \\ \text { Intention to leave } & 0.872\end{array}$

\section{Data Analyses}

To assess our hypotheses, we performed linear regressions (using SPSS software) between career plateauing (structural career plateau (SCP) and content career plateau (CCP)) on the one hand (independent variables), and job satisfaction, commitment and intention to leave the university on the other (dependent variables). As recommended by Mathieu and Zajac (1990), demographic variables such as age, sex, education, job status, and organization tenure were included as potential predictors of organizational commitment and job satisfaction. Recently, Yucel and Bektas (2012) investigated the relationship between teachers' job satisfaction and organizational commitment and evaluated whether teacher age moderates the relationship between job satisfaction and organizational commitment using a set of data from Turkey. They suggested that age differences moderate relationships between teacher job satisfaction and organizational commitment.

To avoid "spurious relationships" we must take into account control variables. Since "education" and "organization tenure" remain constant throughout our sample, we decided to include only "age", "sex" and "job status" (full professor versus assistant professor) as control variables in our model.

Preliminary analysis revealed that "job status" is rarely significant. Hence, even if we are not interested in whether the relationships between the control variables and the dependent variable are statistically significant, we decided to remove this variable. Therefore, we ultimately retained only gender (coded as a dummy variable: 1 for men and 0 for women) and age as control variables and "Structural career plateau" and "Content career plateau" as independent variables. 


\section{Results}

\section{Scholars are Mostly Satisfied and Committed to Their Job and University, but They Express Malaise}

First, we describe the sample of scholars in terms of career plateauing, satisfaction, commitment and intention to leave their university (Table $\underline{3}$ ). We show that despite overall satisfaction and commitment, there is some dissatisfaction within the profession.

Table 3

Mean and standard deviation of the study variables

\section{Variable}

Job satisfaction

Affective organizational commitment

Normative organizational commitment

Affective occupational commitment

Continuance occupational commitment

Normative occupational commitment

Intention to leave

Structural career plateau

Content career plateau

\section{Mean Standard deviation Proportion ${ }^{\mathrm{a}}$}

$3,7370,698$

$3,980 \quad 0,916$

$67.2 \%$

$75.7 \%$

$63.8 \%$

$25.8 \%$

$87.0 \%$

$65.8 \%$

$39.8 \%$

$34.6 \%$

$55.8 \%$

$8.7 \%$

${ }^{a}$ All of the statements were evaluated on a six-point Likert scale, and the mean value was found to be of 3.5. By computing the proportion of respondents with average scores equaling or exceeding this threshold of 3.5 we found, for example, that $67.2 \%$ of the sample are satisfied with their jobs

Notably, scholars in French universities are generally satisfied with their jobs. Considering all the satisfaction dimensions, $67.2 \%$ of scholars are satisfied overall. Meanwhile, satisfaction depends particularly on job stability (mean $=5.20$ ), the freedom offered by the job and interest in the work performed $($ mean $=4.64)$.

Job satisfaction is evident in many subject responses to the open-ended questions at the end of the questionnaire. Thus, for example, some respondents said: "This is a job that has brought me much happiness and the passion to teach students...." (Assistant Professor). "I really like this job" (Full Professor). "For me, this is an exciting job. I like the intellectual part of it. I enjoy my freedom..." (Assistant Professor).

However, there are also strong areas of dissatisfaction, particularly regarding the increasing bureaucratization of the profession (mean $=2.41$ ), wages ( mean $=2.53$ ), career advancement $($ mean $=2.64)$ and working conditions (mean $=3.07$ ). To a lesser extent, the qualitative comments of respondents revealed criticisms of the lack of resources of universities and the difficulty of reconciling private and professional life.

For example, a number of respondents indicated: "Our wages are very low" (Full Professor ); "We are involved in many areas (research, education, administration) and receive little in 
return (I mean pay)!" (Assistant professor); "Our purchasing power relative to other professions has declined considerably" (Assistant professor); "I find that my current wage (and future) does not reflect my level of education and skill" (Full Professor); "Our job has become difficult to juggle with family life" (Assistant Professor); "I think the quality of our work conditions has declined considerably over the past ten years" (Assistant Professor).

Regarding commitment of scholars, it is more affective (i.e. expressed by a statement such as "I love my job") than continuance ("It's better for me to keep my job") or normative ("I feel morally forced to stay at the University"), regardless of whether commitment is organizational or occupational. Thus, concerning organizational commitment, we observe strong affective organizational $(75.7 \%)$ and continuance commitment $(63.8 \%)$, but weak normative organizational commitment $(25.8 \%)$. Additionally, concerning occupational commitment, the affective dimension $(87.0 \%)$ and continuance dimension $(65.8 \%)$ exceed the normative dimension $(39.8 \%)$. Only one third of our sample intended to leave their institutions.

Finally, more than half of the sample expressed the feeling of structural career plateauing $(55.8 \%)$. However, scholars do not perceive their careers to have plateaued in terms of content (91.3\% declared that they remain interested in their jobs). Thus even when they perceive themselves as having little or no chance of promotion, scholars remain interested in the content of their work, and enjoy not only teaching but also being part of research programs and managing educational programs.

\section{The Relationships Between Career Plateauing and Job Satisfaction, Commitment and Intention to Leave are Confirmed}

To verify that the relationship does not actually depend solely on age and gender (the control variables), for each hypothesis we systematically tested two models. The first one (the control model or model 1) included only the two control variables as independent variables ("Sex" and "Age"), while the second (complete model or model 2) added the variables "Structural career plateau (SCP)" and "Content career plateau (CCP)". The next step was to verify that the inclusion of these two variables improves the model quality in terms of $\mathrm{R}^{2}$ and Fisher change.

Whatever the hypothesis tested, the $\mathrm{R}^{2}$ of the full model (model 2) always significantly exceeds that of the control model (model 1). Furthermore, the F Change is always significant.

\section{Research Hypothesis One-Subjective Plateauing Negatively Influences Job Satisfaction}

Table 4 shows a negative relationship between subjective career plateauing, whether structural or content-based, and job satisfaction. This negative relationship confirms hypothesis H1. The link between plateauing and satisfaction clearly shows that the job satisfaction of scholars decreases with increasing feelings of career plateauing. The associated $\mathrm{R}^{2}$ is relatively high since $34.4 \%$ of the variance of satisfaction is explained by plateauing variables. This result confirms previous studies (Chang Bon Lee 2003; Orpen 1983; Veiga 1981) that found scholars feel plateaued, and hence have reduced job satisfaction, either because they have no possibility of future promotion, or because they perceive their work to be boring.

Table 4

Relationship between career plateauing and job satisfaction 
Complete model

Control model - change statistics

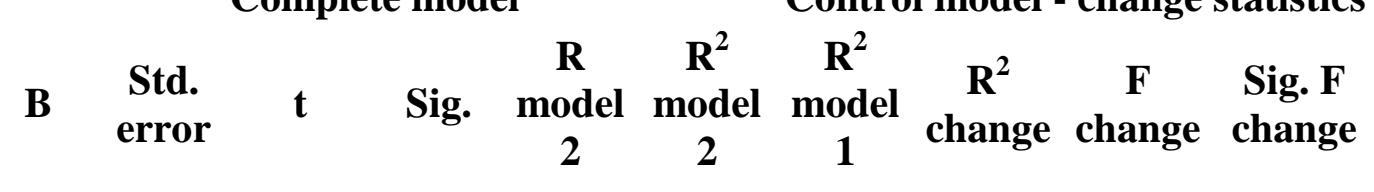

(Constant) $-1.323 \quad 0.253 \quad-5.229 \quad 0.00 \%$

$\begin{array}{lllll}\text { Age } & 0.021 & 0.005 & 3.759 & 0.02 \%\end{array}$

$\begin{array}{lllllllllll}\text { Sex } & 0.615 & 0.089 & 6.947 & 0.00 \% & 0.586 & 0.344 & 0.019 & 0.325 & 480.093 & 0.00 \%\end{array}$

SCP $\quad-0.2440 .024-10.1570 .00 \%$

$\mathrm{CCP} \quad-0.7620 .032-23.4880 .00 \%$

$S C P$ structural career plateau, $C C P$ content career plateau

It is also interesting to note that the coefficients associated with the two control variables are significant and positive. Our results thus show that men are more satisfied with their jobs than women. Similarly, job satisfaction appears to increase with scholar age.

\section{Research Hypothesis Two-Subjective Plateauing Negatively Influences Organizational}

\section{Commitment}

Organizational commitment is traditionally divided into three dimensions: affective, continuance and normative. Therefore, we test the impact of career plateauing (structural and content) on each of these three dimensions.

- Research hypothesis two-A-Subjective plateauing negatively influences affective organizational commitment

We can verify that the more scholars feel plateaued, the less they are affectively committed to their university. Moreover, we observe that age positively influences affective organizational commitment, and older scholars are more committed. Additionally, men are more affectively committed than women (Table $\underline{5}$ ).

Table 5

Relationship between career plateauing and affective organizational commitment

\begin{tabular}{llllll} 
Complete model & & & \multicolumn{2}{c}{ Control model - change } \\
Statistics
\end{tabular}

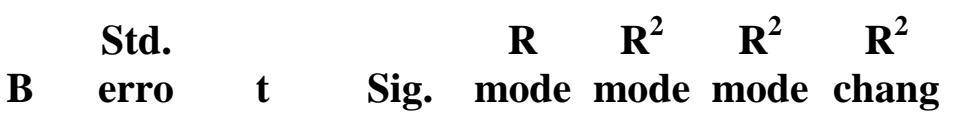

$\mathbf{r}$

12

(Constant -1.24

)

Age

Sex

$0.207-6.019$

0.00 $\%$

$\begin{array}{lll}0.024 & 0.0045 .313 \quad 0.00\end{array}$
0.255
0.0723 .521
0.04
$\%$

$\begin{array}{lll}0.434 & 0.188 & 0.016\end{array}$

0.173

$206.780 .00 \%$ 
Complete model

Control model - change statistics

$S C P$ structural career plateau, $C C P$ content career plateau

- Research hypothesis two-B-Subjective plateauing negatively influences normative organizational commitment

In terms of the normative dimension of organizational commitment, the expected links are also confirmed. We observe a negative relationship between career plateauing and normative organizational commitment. Furthermore, normative organizational commitment increases with age and women are less normatively committed than men (Table $\underline{6}$ ).

Table 6

Relationship between career plateauing and normative organizational commitment

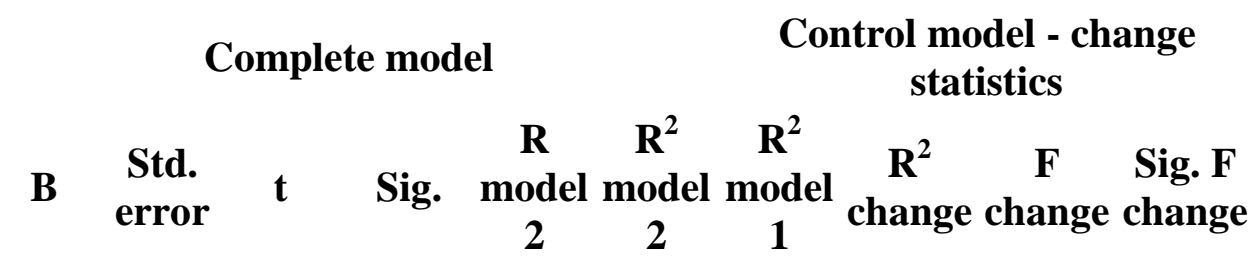

(Constant) $-1.6380 .223-7.3470 .00 \%$

Age $\quad 0.033 \quad 0.0056 .849 \quad 0.00 \%$

$\begin{array}{lllllllllll}\text { Sex } & 0.207 & 0.078 & 2.655 & 0.80 \% & 0.308 & 0.095 & 0.020 & 0.075 & 80.664 & 0.00 \%\end{array}$

SCP $\quad-0.1250 .021-5.8890 .00 \%$

$\mathrm{CCP} \quad-0.2370 .029-8.2990 .00 \%$

$S C P$ structural career plateau, $C C P$ content career plateau

- Research hypothesis two-C-Subjective plateauing negatively influences continuance organizational commitment

The results for the continuance dimension of organizational commitment are more unexpected. While our study shows a link between plateauing and organizational continuance commitment, it is positive instead of negative. This surprising result differs from previous results obtained by studies on the private sector. 
However, since the associated $\mathrm{R}^{2}(0.129)$ value is rather weak, we must be very careful when interpreting the data.

If we nevertheless take this relationship into account, it signifies that the more scholars are plateaued, the higher their continuance organizational commitment. Scholars who feel plateaued believe that despite apparently poor wages and a lack of professional development, it is still preferable to keep their jobs. This feeling is illustrated in the following comments:

"One of the biggest advantages of being a scholar is feeling free to organize ourselves as we want. And we have job security. For me, these are the main advantages that counterbalance the low wages compared with the private sector." Scholars do not want to leave their university because they are aware their jobs provide benefits compared with the private sector. Moreover, they do not see attractive alternatives. Thus, the profession of scholars and its particular status seem to have some specificities that can negate relationships established between plateauing and commitment in the literature on the private sector. Additionaly, it seems that age is not relevant. On the other hand, women have stronger continuance organizational commitment than men (Table $\underline{7}$ ).

Table 7

Relationship between career plateauing and continuance organizational commitment

\begin{tabular}{|c|c|c|c|c|c|c|c|c|c|}
\hline & \multicolumn{5}{|c|}{ Complete model } & \multicolumn{4}{|c|}{$\begin{array}{c}\text { Control model - change } \\
\text { statistics }\end{array}$} \\
\hline & $\mathbf{B}$ & $\begin{array}{l}\text { Std. } \\
\text { erro } \\
\mathbf{r}\end{array}$ & Sig. & $\begin{array}{c}R \\
\text { mode } \\
12\end{array}$ & $\begin{array}{c}\mathbf{R}^{2} \\
\text { mode } \\
12\end{array}$ & $\begin{array}{c}\mathbf{R}^{2} \\
\text { mode } \\
\mathbf{l} 1\end{array}$ & $\begin{array}{c}\mathbf{R}^{2} \\
\text { chang } \\
\mathbf{e}\end{array}$ & $\underset{\text { change }}{F}$ & $\begin{array}{c}\text { Sig. F } \\
\text { chang } \\
\text { e }\end{array}$ \\
\hline (Constant & 0.390 & 0.2011 .940 & $5.25 \%$ & & & & & & \\
\hline Age & $\begin{array}{l}-0.00 \\
5\end{array}$ & $0.004_{8}^{-1.10}$ & $\begin{array}{l}26.80 \\
\%\end{array}$ & & & & & & \\
\hline Sex & $\begin{array}{l}-0.25 \\
5\end{array}$ & $0.070_{9}^{-3.62}$ & $0.03 \%$ & 0.360 & 0.129 & 0.011 & 0.119 & $\begin{array}{l}132.19 \\
0\end{array}$ & $0.00 \%$ \\
\hline $\mathrm{SCP}$ & 0.210 & 0.01911 .006 & $0.00 \%$ & & & & & & \\
\hline $\mathrm{CCP}$ & 0.182 & 0.0267 .082 & $0.00 \%$ & & & & & & \\
\hline
\end{tabular}

$S C P$ structural career plateau, $C C P$ content career plateau

Research Hypothesis Three-Subjective Plateauing Negatively Influences Occupational

\section{Commitment}

Like organizational commitment, occupational commitment is usually divided into three dimensions, and so we once again tested three distinct hypotheses.

- Research hypothesis three-A — Subjective plateauing negatively influences affective occupational commitment

We observed that the more scholars feel career plateaued, the lower their affective commitment to their jobs. This link between career plateauing and affective occupational 
commitment is strong $\left(\mathrm{R}^{2}=0.523\right)$. Also, males and older scholars show more affective commitment than females and younger scholars (Table $\underline{8}$ ).

Table 8

Relationship between career plateauing and affective occupational commitment

\section{Complete model}

Control model - change statistics

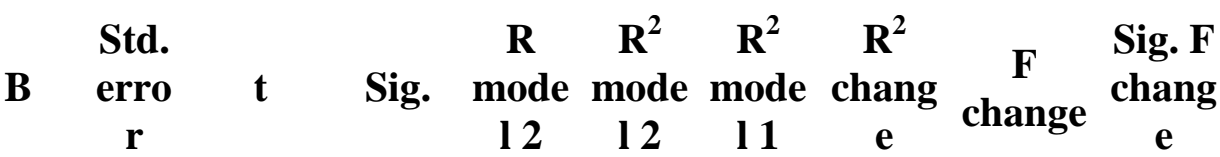

$\begin{array}{llll}\text { (Constant } & -0.64 & 0.155-4.147 & 0.00\end{array}$

$\begin{array}{lll}\text { Age } \quad 0.011 \quad 0.0033 .184 & \begin{array}{l}0.15 \\ \%\end{array}\end{array}$

$\begin{array}{llllllllll}\text { Sex } & 0.253 & 0.0544 .658 & \begin{array}{l}0.00 \\ \%\end{array} & 0.723 & 0.523 & 0.007 & 0.516 & \begin{array}{l}1052.0 \\ 0\end{array} & 0.00 \%\end{array}$

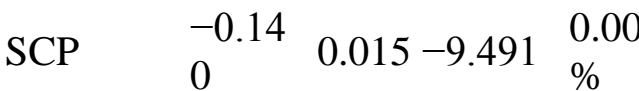

$\begin{array}{llll}\mathrm{CCP} & -0.76 & 0.020 & \begin{array}{ll}-38.24 & 0.00 \\ \%\end{array}\end{array}$

$S C P$ structural career plateau, $C C P$ content career plateau

- Research hypothesis three-B-Subjective plateauing negatively influences normative occupational commitment

Table $\underline{9}$ confirms the negative relationship between subjective plateauing and the normative dimension of occupational commitment, though the link is weak $\left(\mathrm{R}^{2}=0.083\right)$. Once again, men are more normatively committed to their job than women, and younger scholars are less normatively committed than older ones.

Table 9

Relationship between career plateauing and normative occupational commitment

Complete model

Control model - change statistics

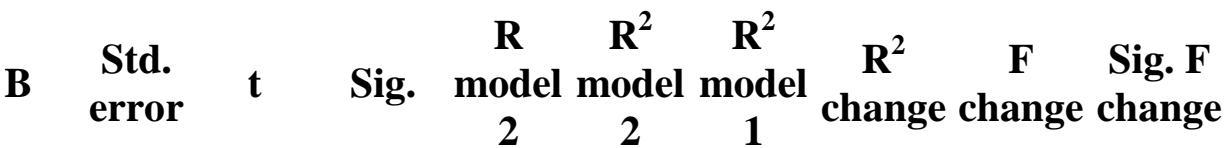

(Constant) $-1.7050 .186-9.1900 .00 \%$

Age $\quad 0.033 \quad 0.0048 .336 \quad 0.00 \%$

$\begin{array}{lllllllllll}\text { Sex } & 0.279 & 0.065 & 4.300 & 0.00 & 0.288 & 0.083 & 0.040 & 0.043 & 45.059 & 0.00 \%\end{array}$

SCP $\quad-0.0780 .018-4.4180 .00 \%$ 


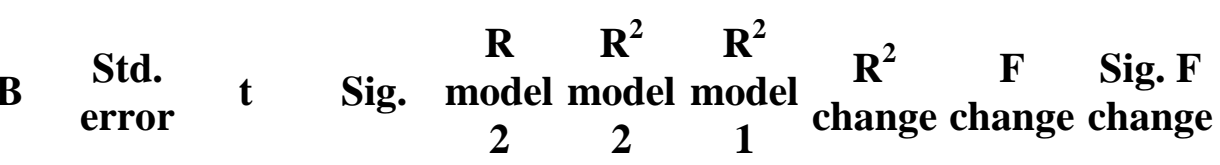

$\mathrm{CCP} \quad-0.1470 .024-6.1890 .00 \%$

$S C P$ structural career plateau, $C C P$ content career plateau

- Research hypothesis three-C-Subjective plateauing negatively influences continuance occupational commitment

As for organizational commitment, unexpected results are obtained for continuance occupational commitment. Indeed, the link is positive: even if scholars feel career plateaued, they calculate it is better for them to remain in their job. However, the value of $\mathrm{R}^{2}$ is weak.

Concerning the control variables, sex is not significant, and so no clear differences exist between women and men. On the other hand, age is relevant, and older scholars have stronger continuance occupational commitment than younger ones (Table 10).

Table 10

Relationship between career plateauing and continuance occupational commitment

\section{Complete model}

$$
\begin{array}{llll}
\mathbf{R} & \mathbf{R}^{2} & \mathbf{R}^{2} & \mathbf{R}^{2}
\end{array}
$$

\section{Control model - change} statistics

\author{
B $\underset{\text { error }}{\text { Std. }} \mathbf{t}$

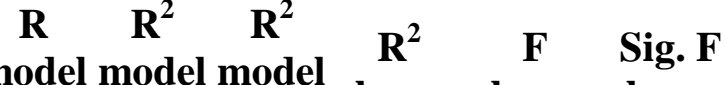 \\ $\begin{array}{lll}2 & 2 & 1\end{array}$

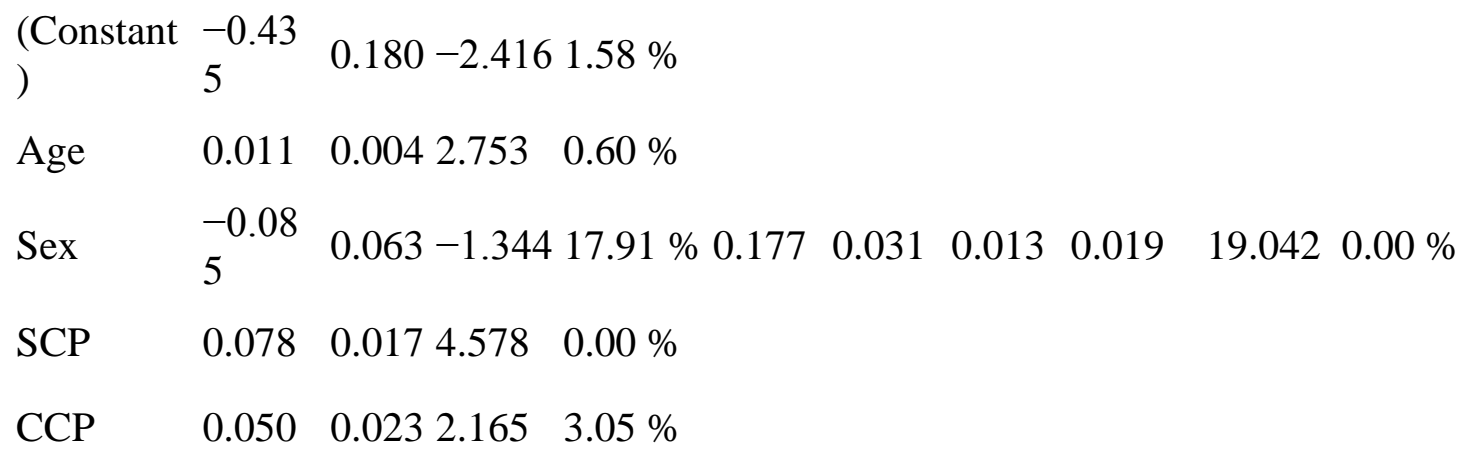 \\ $S C P$ structural career plateau, $C C P$ content career plateau \\ Consequently, hypothesis 2 and 3 are partially confirmed.
}


A positive relationship exists between subjective plateauing (in terms of structure or job content) and intention to leave the organization, which confirms hypothesis 4 . However, this relationship is weak $\left(\mathrm{R}^{2}=0.117\right)$. Consistent with the literature, a relationship is observed between subjective job content plateauing and intention to leave the institution.

Additionally, males and young scholars are more likely to be inclined to leave the organization than are females and older scholars (Table $\underline{11}$ ).

Table 11

Relationship between career plateauing and intention to leave

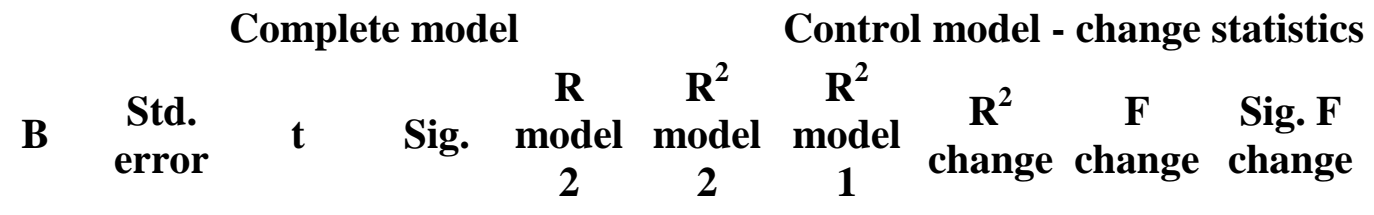

(Constant) $2.255 \quad 0.200 \quad 11.268 \quad 0.00 \%$

Age $\quad-0.0520 .004-12.0290 .00 \%$

$\begin{array}{lllllllllll}\text { Sex } & 0.183 & 0.070 & 2.612 & 0.91 \% & 0.343 & 0.117 & 0.071 & 0.046 & 50.945 & 0.00 \%\end{array}$

$\begin{array}{lllll}\mathrm{SCP} & 0.057 & 0.019 & 2.995 & 0.28 \%\end{array}$

$\begin{array}{lllll}\mathrm{CCP} & 0.202 & 0.026 & 7.863 & 0.00 \%\end{array}$

$S C P$ structural career plateau, $C C P$ content career plateau

\section{Discussion}

The present study investigated the relations between career plateauing and satisfaction, commitment and intention to leave the organization in French universities. The results clearly demonstrate that scholars feel career-plateaued, and that this feeling can negatively impact their behavior. This confirms the impact of career plateauing on job satisfaction, organizational commitment, occupational commitment and intention to leave. As previously quoted, subjective structural and job content plateauing decrease job satisfaction, affective and normative commitment (organizational and occupational) and intention to leave the organization.

However compared with studies on the private sector, the results of this study on the public sector show some differences. As expected, we observe an inverse relationship (albeit weak) between career plateauing and continuance commitment. That means career plateaued scholars still prefer to stay in their universities and do not see other attractive jobs. However, they feel less emotionally involved in their universities (affective commitment) and do not consider they have to stay (normative commitment). This result might be linked to recent changes affecting French universities (including the areas of university autonomy, teacher evaluation, etc.). Scholars consequently may feel a gap between the initial values that lead them to join their universities, and current and new values based on efficiency and efficacy 
(Authors 2013). Consequently, the link between career plateauing and intention to leave university is positive but weak. Scholars have opposite feelings about their reasons for leaving or remaining at the university when being plateaued. On the one hand, they like teaching and appreciate freedom and job stability, but on the other hand, they express dissatisfaction in terms of wages and career development.

These results suggest several major conclusions both from a theoretical and practical perspective.

First, they confirm previous theoretical results regarding relationships between subjective career plateauing (in terms of job content and structure) and key variables in the field of human resource management: satisfaction, intention to leave and organizational and occupational commitment. The results further confirm relationships that thus far remain exploratory or controversial. They also show the relevance of career plateauing based on two distinct dimensions: subjective job content plateauing and subjective structural plateauing. Indeed, the regression analysis identifies differences between these two dimensions.

From a practical perspective, the results are interesting in that they can help public French administrators manage the careers of scholars. More than half of the scholars questioned felt structurally plateaued. Measures that could undoubtedly help alleviate these feelings of career plateauing would include favoring mobility, facilitating movements between universities, encouraging interdisciplinarity between scholars and promoting exchanges between the academic and professional worlds.

Notably, women feel slightly more plateaued and less satisfied than their male colleagues. Women are also less committed except in terms of continuance commitment, but on the other hand are less likely to leave their organizations. These results raise additional questions, namely: what is the place of women in French universities? Also, why are they more plateaued than male scholars? Gender can be a response. The fact that French female scholars feel more plateaued than male may be linked with a glass ceiling. Indeed, figures indicate that female scholars are less professors (19,9\% of professors are women) (Authors 2013). This result might explain why they are less satisfied and committed than their male colleagues. This result might explain why they are less satisfied than their male colleagues.

Regarding age, older scholars are more committed (organizational and occupational), more satisfied and have lower intention to leave their universities.

To extend this research, we suggest exploring the link between performance and career plateauing. This link has already been studied in the private sector. Indeed, literature on plateauing suggests that performance should not necessarily decrease because career plateauing is not necessarily a reflection of poor performance (Barwick 1986; Near 1985; Camazza et al. 1981; Ference et al. 1977). In the context of university reforms, this question of the relationship between scholar's performance and career plateauing becomes important, especially given that scholars face increasingly close evaluation.

\section{Footnotes}

1. 1 . 
The authors thank the Trade Union for allowing us to use their data. Their data file includes both scholars who are union members and those who are not, and hence can be considered to closely approximate the entire population of scholars at French universities.

2. 2 .

Demographic characteristics of teaching personnel working in French higher education (2008/2009), DGRH A1 - 1, June 2009.

\section{Appendix}

Table 12

Structure of the sample compared to overall population of scholars in France-all disciplines

Characteristics of our sample

Full professors

Assistant professors

$\begin{array}{llll}\text { Men } & \text { Women } & \text { Men } & \text { Women } \\ 78.1 \% & 21.9 \% & 61.0 \% & 39.0 \%\end{array}$

Average age: 52 years (men) and 49 years

(women)

Average age: 43 years (men and women)

Characteristics of the profession

Source: Ministry of higher education teaching and research, Studies and statistics ("Etudes et regards statistiques”), 25 March 2011

Full professors

$\begin{array}{ll}\text { Men } & \text { Women } \\ 80.0 \% & 20.0 \%\end{array}$

Average age: 52 years
Assistant professors

$\begin{array}{ll}\text { Men } & \text { Women } \\ 58.5 \% & 41.5 \%\end{array}$

Average age: 44 years

\section{References}

1. Allen, N., \& Meyer, J. (1990). Measurements and antecedents of affective, continuance and normative commitment to the organization. Journal of Occupational Psychology, 63, 3242.CrossRefGoogle Scholar

2. Allen, N., Meyer, J., \& Smith, C. (1993). Commitment to organizations and occupations : extension and test of a three component conceptualization. Journal of Applied Psychology, 78, 538-551.CrossRefGoogle Scholar

3. Allen, T. D., Russell, J. E., Poteet, M. L., \& Dobbins, G. H. (1999). Learning and development factors related to perceptions of job content and hierarchical plateauing. Journal of Organizational Behavior, 20(7), 1113-1137.CrossRefGoogle Scholar

4. Aranya, N., Pollock, J., \& Armenic, J. (1981). An examination of professional commitment in public accounting. Accounting, Organization and Society, 7, 201-216.CrossRefGoogle

$\underline{\text { Scholar }}$

5. Authors (2013).Google Scholar

6. Barley, S. R. (1989). Careers, identity and institutions. In M. B. Arthur, D. T. Hall, \& B. S. Lawrence (Eds.), The handbook of career theory (pp. 41-60). Cambridge: Cambridge University Press.CrossRefGoogle Scholar

7. Barwick, J. M. (1986). The plateauing trap. New York: Amacom.Google Scholar

8. Blau, G. J. (1989). Testing the generalizability of a career commitment measure and its impact on employee behavior. Journal of Vocational Behavior, 35, 88-103.CrossRefGoogle Scholar 
9. Buitendach, J. H., \& De Witte, H. (2005). Job insecurity, extrinsic and intrinsic job satisfaction and affective organizational commitment of maintenance workers in a parastatal. South African Journal of Business Management, 36(2), 27-37.Google Scholar

10. Burke, R. J. (1989). Examining the career plateau: some preliminary findings. Psychological Reports, 65, 295-306.CrossRefGoogle Scholar

11. Camazza, Korman, Ference, \& Stoner. (1981). Plateaued and non plateaued managers: factors in job performance. Journal of Management, 7, 7-27.Google Scholar

12. Chang Bon Lee, P. (2003). Going beyond career plateau: using professional plateau to account for work outcomes. Journal of Management Development, 22(6), 538-551.CrossRefGoogle Scholar

13. Churchill, G. A. (1979). A paradigm for developing better measures of marketing constructs. Journal of Marketing Research, 16, 64-73.CrossRefGoogle Scholar

14. Ference, T. P., Stoner, J. A. \& Warren, E. K. (1977). Managing the career plateau. Academy of Management Review, October, 602-612.Google Scholar

15. Foote, N. (1951). Identification as the basis for a theory of motivation. American Sociological Review, 16(1), 14-21.CrossRefGoogle Scholar

16. Gattiker, U. E., \& Larwood, L. (1990). Predictors for careers advancement in the corporate hierarchy. Human Relations, 43(8), 703-726.CrossRefGoogle Scholar

17. Hall, D. T. (1985). Project work as an antidote to career plateauing in a declining engineering organization. Human Resource Management, 24(3), 271-292.CrossRefGoogle Scholar

18. Hosseini, M., Asefzadeh, S., Nejati, M., \& Sadejhi, T. (2013). Medical universities strategic plan: progress and related obstacles. Public Organizational Review, 7(4), 1290-1294.Google $\underline{\text { Scholar }}$

19. Kanungo, R. N. (1982). Measurement of job and work involvement. Journal of Applied Psychology, 67(3), 341-349.CrossRefGoogle Scholar

20. Lemire, L., Saba, T., \& Gagnon, Y. C. (1999). Managing career plateauing in the Quebec public sector. Public Personnel Management, 28(3), 375-391.CrossRefGoogle Scholar

21. Locke, E. (1969). What is job satisfaction? Organizational Behavior and Human Performance, 4, 309-336.CrossRefGoogle Scholar

22. Machado, M. L., \& Gouveia, O. (2011) Academic satisfaction as an amplifier of the organizational intellectual capital. Proceedings of the European Conference on Intellectual Capital, pp. 199-205.Google Scholar

23. Maden, C. (2012). Transforming public organizations into learning organizations: a conceptual model. Public Organizational Review, 12(1), 71-84.CrossRefGoogle Scholar

24. Mathieu, J. E., \& Zajac, D. (1990). A review and meta-analysis of the antecedents, correlates, and consequences of organizational commitment. Psychological Bulletin, 108, 171194.CrossRefGoogle Scholar

25. Meyer, J. P., \& Allen, N. J. (1984). Testing the "side-bet theory" of organizational commitment: some methodological considerations. Journal of Applied Psychology, 69, 372 378.CrossRefGoogle Scholar

26. Meyer, J. P., \& Allen, N. J. (1991). A three-component conceptualization of organizational commitment. Human Resource Management Review, 1, 61-89.CrossRefGoogle Scholar

27. Meyer, J. P., \& Allen, N. J. (1997). Commitment in the workplace: Theory, research, and application. Thousand Oaks: Sage.Google Scholar

28. Meyer, J. P., Stanley, D. J., Herscovitch, L., \& Topolnytsky, L. (2002). Affective, continuance, and normative commitment to the organization: a meta-analysis of antecedents, correlates, and consequences. Journal of Vocational Behavior, 61, 20-52.CrossRefGoogle Scholar

29. Miles, M. B., \& Huberman, A. M. (1994). Analyse des données qualitatives : Recueil de nouvelles méthodes. Bruxelles: De Boeck Université.Google Scholar

30. Milliman, J. F. (1992). Causes, consequences and moderating factors of career plateauing. Doctoral Dissertation, University of Southern California.Google Scholar

31. Morrow, P. C., \& Wirth, R. E. (1989). Work commitment among salaried professionals. Journal of Vocational Behavior, 34, 40-56.CrossRefGoogle Scholar 
32. Mowday, R. T. (1998). Reflections on the study and redevance of organizational commitment. Human Resource Management Review, 8(n²), 387-401.CrossRefGoogle Scholar

33. Mowday, R. T., Steers, R. M., \& Porter, L. W. (1979). The measurement of organizational commitment. Journal of Vocational Behavior, 14, 224-227.CrossRefGoogle Scholar

34. Near, J. P. (1985). A discriminant analysis of plateaued versus non plateaued managers. Journal of Vocational Behavior, 26, 177-188.CrossRefGoogle Scholar

35. Orpen, C. (1983). The career patterns and work attitudes of plateaued and non-plateaued managers. International Journal of Manpower, 4(4), 32-36.CrossRefGoogle Scholar

36. Roger, A., \& Lapalme, M. E. (2006). L'individu face au plafonnement de carrière. In Comportement organizationnel, vol.2, coord. El Akremi, De Boeck Université, Méthodes et Recherches, 223-242.Google Scholar

37. Rosen, B., \& Jerdee, T. H. (1988). Managing older workers' careers'. In R. Rowland \& G. Ferris (Eds.), Research in personnel and human resources management. Greenwich: JAI Press, 6, 37-71.Google Scholar

38. Savery, L. K. (1989). The influence of job factors on employee satisfaction. Journal of Managerial Psychology, 4(1), 27-31.CrossRefGoogle Scholar

39. Slocum, J. W., Cron, W. L., Hansen, R. W., \& Rawlings, S. (1985). Business strategy and the management of the plateaued employee. Academy of Management Journal, 28, 133154.CrossRefGoogle Scholar

40. Spector, P. E. (1997). Job satisfaction. Application, assessment, causes, and consequences. Thousand Oaks: Sage Publications, Inc.CrossRefGoogle Scholar

41. Stoner J. A., Ference, T. P., Warren, E. K., \& Christensen, H. K. (1980). Managerial career plateaus. In Career development. NY Center for Research, Columbia University.Google Scholar

42. Tremblay, M., \& Roger, R. A. (1993). Individual, familial, and organizational determinants of career plateau. Group \& Organization Management, 18(4), 411-435.CrossRefGoogle Scholar

43. Tremblay, M., Roger, R. A., \& Toulouse, J. M. (1995). Career plateau and work attitudes: an empirical study of managers. Human Relations, 48(3), 221-237.CrossRefGoogle Scholar

44. Veiga, J. F. (1981). Plateaued versus nonplateaued managers: career patterns, attitudes, and path potentials. Academy of Management Journal, 24(3), 566-578.CrossRefGoogle Scholar

45. Wegge, J., Schmidt, K., Parkes, C., \& Van Dick, K. (2007). Tacking a Sickie's: job satisfaction and job involvement as interactive predictors of absenteeism in a Public Organization. Journal of Occupational and Organizational Psychology, 80, 7789.CrossRefGoogle Scholar

46. Weiss, D. J., Davis, R. V., England, G. W. \& Loftquist, L. H. (1967). Manual for the Minnesota Satisfaction Questionnaire. Minnesota studies in vocational rehabilitation: XXII, Minnesota University. Google Scholar

47. Yucel, I., \& Bektas, C. (2012). Job satisfaction, organizational commitment and demographic characteristics among teachers in Turkey: younger is better? Social and Behavioral Sciences, 46, 1598-1608. Google Scholar 